\title{
Türk Halk Müziği ve Türk Sanat Müziği Teorisi ve Uygulaması Derslerine İlişkin Öğretim Elemanı Görüşleri
}

\author{
Taner TOPALOĞLU \\ Harran Üniversitesi \\ tanertopaloglu@ harran.edu.tr \\ ORCID ID: 0000-0002-2095-3672 \\ Şenol AFACAN \\ Kırşehir Ahi Evran Üniversitesi \\ senolafacan@gmail.com \\ ORCID ID: 0000-0001-7564-1695
}

\begin{tabular}{|c|c|c|}
\hline Araştırma Makalesi & & DOI: $10.31592 /$ aeusbed.737409 \\
\hline Geliş Tarihi: 15.05 .2020 & Revize Tarihi: 21.10 .2020 & Kabul Tarihi: 23.10 .2020 \\
\hline
\end{tabular}

\section{Atıf Bilgisi}

Topaloğlu, T. ve Afacan, Ş. (2020). Türk Halk Müziği ve Türk Sanat Müziği Teorisi ve Uygulamasi derslerine ilişkin öğretim elemanı görüşleri. Ahi Evran Üniversitesi Sosyal Bilimler Enstitüsü Dergisi, 6(3), 780-793.

\section{ÖZ}

2018 Yılında Yüksek Öğretim Kurumunun Eğitim Fakültelerinin Müzik Eğitimi lisans programlarında yaptığı değişiklik sonucunda Türk Halk Müziği Teorisi ve Uygulaması ile Türk Sanat Müziği Teorisi ve Uygulaması dersleri eklenmiştir. Bu çalışmanın amacı programa yeni eklenen Türk Halk Müziği ve Türk Sanat Müziği Teorisi ve Uygulaması derslerini öğretim elemanlarının görüşleri doğrultusunda incelemektir. $\mathrm{Bu}$ amaçla öğretim elemanlarına bu derslerde kullanılabilecek ses sistemi, enstrümanlar, kaynaklar ve öğretim programında ayrılan ders sürelerinin yeterliliği gibi konulara açıklık getirmek için çalışma kapsamında hazırlanan yarı yapılandırılmış görüşme formu uygulanmıştır. Araştırmada nitel araştırma yöntemlerinden durum deseni kullanılmıştır. Elde edilen veriler içerik analizi yöntemi ile analiz edilmiştir. Çalışma sonucunda, Türk Halk Müziği Teorisi ve Uygulaması dersi için öğretim programında ayrılan ders süresinin yeterli olduğu, ders içi uygulamalarda 17 ses sisteminin kullanılmasının ve bu ses sistemine uygun perdeli bir çalgı olan bağlama enstrümanının kullanımının uygun olacağı ve mevcut kaynakların sınırlı sayıda olduğu belirlenmiștir. Türk Sanat Müziği Teorisi ve Uygulaması dersi için öğretim programında ayrılan ders süresinin yeterli olduğu, ders içi uygulamalarda 24 ses sisteminin kullanılmasının uygun olduğu, ders içi uygulamalarda kanun enstrümanının ses gürlüğü ve perdeli bir çalgı olmasından dolayı kullanışlı olacağı, mevcut kaynakların sayısal olarak kısmen yeterli olduğuna ilișkin sonuçlara ulaşılmıştır.

Anahtar Kelimeler: Türk halk müziği, Türk sanat müziği, müzik teorisi, müzik eğitimi.

\section{Instructors' Opinions on the Courses: Turkish Folk Music and Turkish Classical Music Theory and Practice}

\begin{abstract}
In 2018, two courses titled Turkish Classical Music Theory and Practice and Turkish Classical Music Theory and Practice have been included in the undergraduate teaching program according to the changes made by the Council of Higher Education. The purpose of this study is to analyse the courses, Turkish Classical Music Theory and Practice and Turkish Classical Music Theory and Practice, which have been recently introduced, based on the opinions of the instructors. For this purpose, a semi-structured interview form that was prepared in the scope of the study was performed with the instructors to clarify the issues such as the sound system, instruments, sources and sufficiency of the lecture hours allocated within the study program. The study was designed as a case study and employed a qualitative research methodology. The collected data was analysed using the content analysis method. The study results of the study revealed that the allocated lecture time for the Turkish folk music theory and practice in the study program is sufficient, using 17 sound system for inclass practices is appropriate and baglama, which is a fretted instrument, is a proper instrument for the sound system, and the available sources are limited. On the other hand, the results also revealed that the time allocated for Turkish Classical Music Theory and Practice in the study program was sufficient, using 24 sound system for in-class practices is appropriate, it might be appropriate to use qanun, which is a fretted instrument, is a proper instrument for the of sound system, and the number of available sources are partially sufficient.
\end{abstract}

Keywords: Turkish folk music, Turkish classical music, music theory, music education 


\section{Giriş}

Türkiye'de müzik eğitimi üç alanda verilmektedir. Bunlar genel müzik eğitimi, özengen ve mesleki müzik eğitimidir. Uçan (2005) genel, özengen (amatör) ve mesleki (profesyonel) amaçlı müzik eğitimini nitelikleri yönünden bakıldığında, aralarında belli ortak noktalar bulunmakla birlikte, birbirlerinden oldukça farklı özellikleri de içinde barındırdığını ifade etmektedir. Ana amaç ve hedef kitle olarak bakıldığında müzik türlerinin içinde mesleki müzik eğitiminin diğerlerinden ayrıldığı görülmektedir. Tarman (2006) mesleki müzik eğitiminin diğer türlerden farklı olarak Müziği meslek olarak seçmek isteyen kişilere yönelik olduğunu ve mesleki müzik eğitimine başlayabilmek için, belli düzeyde müzik yeteneğine sahip olması gerektiğini belirtmektedir.

$\mathrm{Bu}$ yönüyle değerlendirecek olursak müziği meslek olarak seçmek isteyenlerin Türkiye'de mesleki müzik eğitimi veren eğitim fakültelerinin müzik eğitimi bölümleri, Konservatuar, Güzel sanatlar fakültelerinin müzik bilimleri bölümleri ve Anadolu güzel sanatlar liselerinin açmış olduğu özel yetenek sınavlarında başarılı olması gerekmektedir.

Mesleki müzik eğitimi veren bu kurumların açmış olduğu yetenek sınavlarında başarılı olan öğrencilerin, seçmiş olduğu bölüme ilişkin hazırlanmış olan eğitim-öğretim programını belirlenen sürede başarı ile bitirmesi beklenmektedir. Müzik eğitimi bölümleri mesleki müzik eğitimi veren önemli kurumlardandır. Özel yetenek sınavı ile öğrenci alan bu kurumlarda lisans ve lisansüstü eğitim verilmekte, mesleki, özengen ve genel müzik eğitimi veren kurumlarda görev alabilecek alana özgü bilgi, beceri ve teknik donanıma sahip eğitimcilerin yetiştirilmesi amaçlanmaktadır.

Bilindiği gibi müzik öğretmeni örgün genel müzik eğitiminin en temel ve en etkin öğelerinden biridir. Genel müzik eğitiminin amaçları (hedefleri) doğrultusunda öğrenciye belirli müziksel davranışlar kazandırmak veya öğrencide belirli müziksel davranış değişiklikleri oluşturmakla yükümlüdür. Bu yükümlülük çerçevesindeki görevlerin üstesinden gelebilmek için belirli ortamlarda belirli etkileşimlerle kazanılan belirli niteliklere sahip olmak zorundadır (Bilgin, 1998, s.8).

Mesleki müzik eğitimi, müziğe belirli düzeyde yatkın olup, müziğin bir dalını kendisine çalışma alanı/meslek olarak seçen kişilere, formal olarak, örgün eğitim kurumlarında verilen müzik eğitimidir. Mesleki müzik eğitimi bireye, çalışma alanı olarak seçtiği dalın gerektirdiği müziksel birikimi ve müziksel davranışları kazandırmayı amaçlar (Er, 2012, s.3).

Genel olarak müzik eğitimi alanı Yıldız'a (2013) göre müziksel işitme, çalma ve söyleme ile müzik bilgisi ve kültürü alanlarından oluştuğu söylenebilir. Müziksel işitme ve okuma becerileri, müzikle uğraşan bireyler için gerekli olan bir alandır. Bu derslerde yapılan çalışmalar, sesler arasındaki farkları algılamaktan, ezgisel algııı geliştirmeye, müzikle ilgili çeşitli kuramsal bilgilerden işitsel belleği geliştirmeye kadar pek çok bilgi ve becerileri kazandırmayı amaçlamaktadır. Bu yönüyle özellikle mesleki müzik eğitimi açısından müziksel işitme, okuma ve yazma bir temel alan niteliğini taşımaktadır ve ders içeriğindeki bilgiler müziğin diğer alanlarının hazır bulunuşluk düzeylerini arttırıcı bir öneme sahiptir (Yıldız, 2013, s. 1).

Hasar'a (2016) göre müziğin akademik boyutunun temel alanı, birçok müzik eğitimcisi tarafından kabul görmüş olan "müziksel işitme okuma ve yazma" eğitimidir ve mesleki müzik eğitimi alanına adım atan bireyler temel müzik bilgilerinin önemli bir kısmını bu ders aracılı̆̆ ile öğrenirler ve pekiştirirler. Müziksel işitme okuma ve yazma dersi müzik bölümlerinde teorik ve pratik olarak uygulanan diğer branş derslerini destekler, geliştirir ve tamamlar. Temel ders niteliği taşır. Öğrencinin müzik alt yapısını oluşturur. Bu dersin içeriğinde yer alan tonal ve makamsal uygulamalar müzik öğretmeni adayının mesleki yeterliliğini arttırır (Öztürk, 2011, s.1).

Yayla'ya (2005) göre müziksel işitme eğitimi, müziğin temel öğelerini kavramak ve bir çalgıyı gerçek anlamda çalmak ya da dinlediğimiz müziği anlamak için gerekli bir çalışmadır. Albuz (1996) Müziksel İşitme Okuma ve Yazma dersinin uygulamada (çalg1, koro, orkestra vb.) teoride (armoni, kontrapunk, müzik biçimleri vb.) derslerinin ön koşulu olduğunu, Müziksel İşitme Okuma ve 
Yazma dersine ilişkin yetersizliğin diğer alan derslerinin de başarısını olumsuz etkileyecektir. Özgür ve Aydoğan (2015) böylesine önemli bir alan dersi olan Müziksel İşitme Okuma ve Yazma dersine yönelik, sesleri müzikal olarak algılayıp ne olduğunu anlama, bir diğerinden ayırt etme ve çözümleme davranışlarını içerdiğini belirtmişlerdir.

Müziksel işitme, herhangi bir müzik yapıtının, algılanması, anlamlandırılması, analiz edilmesi, niteliklerinin belirlenmesi, çözümlenmesi biçiminde ifade edilmektedir. Müziksel (müzikal) işitme; dikey ve yatay ses kümelerinden meydana gelen müzikal sesleri, yükseklik, ritim, tempo ve nüans nitelikleriyle anlayabilmektir (Özçelik, 2010, s.4).

Mesleki müzik eğitiminde önemli bir yere sahip olan Müziksel İşitme Okuma ve Yazma dersi 2018-2019 Eğitim öğretim yılına kadar müzik eğitimi bölümlerinin öğretim programlarının ilk 3 yılında toplam 6 dönem olarak verilmiştir. Bu dersin içerikleri incelendiğinde Türk halk müziği, Türk sanat müziği gibi geleneksel müzik kuramlarının yanında uluslararası müzik türlerine yönelik teorik ve uygulama eğitimlerinin verildiği görülmektedir.

Yüksek Öğretim Kurumunun 2018-2019 Eğitim öğretim y1lında lisans düzeyi öğretim programlarında yaptığı değişiklikle Müziksel İşitme Okuma ve Yazma dersi kaldırılmış ve yerine batı müziği teorisi ve uygulamas1, Türk Halk Müziği Teorisi ve Uygulaması ve Türk Sanat Müziği Teorisi ve Uygulaması dersleri eklenmiştir. Programa ilave edilen bu dersler bağımsız bir disiplin olarak düşünüldügünde kendine ait kaynaklarının olması, öğretim metot ve tekniklerinin kullanılması gerekliliği önem arz etmektedir. Ayrı bir disiplin olarak yeni uygulamaya konulan bu derslerin, müzik öğretmeni yetiştiren müzik eğitimi anabilim dallarında nasıl uygulanacağına ilişkin farklı soruları da beraberinde getirdiği düşünülmektedir. Geleneksel müziğimizin temelini oluşturan Türk Halk Müziği Teorisi ve Uygulaması ve Türk Sanat Müziği Teorisi ve Uygulaması derslerinin hangi ses sistemi ile hangi enstrüman eşliğinde yürütüleceği, derste kullanılabilecek mevcut kaynakların sayısal yeterliliği ve bu dersler için öğretim programında ayrılan ders sürelerinin yeterliliği gibi sorular bunlardan bazılarıdır.

İlk defa verilecek olan bu derslerin uygulanması aşamasında aksaklıkların yaşanmaması, daha nitelikli bir eğitimin verilebilmesi, ders veren öğretim elemanlarına ve literatüre sağlayacağı katkılar açısından değerlendirildiğinde ilgili öğretim elemanlarının bu derslere ilişkin görüşlerinin önemli olduğu düşünülmektedir.

\section{Problem Cümlesi}

Araştırmanın problem cümlesi, 2018-2019 Eğtim öğretim yılında Yüksek Öğretim Kurumu tarafından uygulamaya konulan müzik eğitimi programında ilk olarak uygulanacak "Türk Halk Müziği Teorisi ve Uygulaması ile Türk Sanat Müziği Teorisi ve Uygulaması derslerine ilişkin öğretim elemanları görüşleri nelerdir?” şeklindedir.

\section{Araştırmanın Amacı}

Bu çalışmanın amacı, 2018-2019 Eğitim öğretim yılında uygulamaya konulan müzik eğitimi programı kapsamında ilk olarak uygulanacak olan Türk Halk Müziği Teorisi ve Uygulaması, Türk Sanat Müziği Teorisi ve Uygulaması derslerinde kullanılacak olan ses sistemi, enstrüman, kaynaklar, programda ayrılan ders süresi ve dersin uygulanmasına ilişkin öğretim elemanlarının görüşlerini tespit etmektir.

\section{Yöntem}

Bu bölümde araştırmanın modeli, çalışma grubu, veri toplama araçları ve verilerin analizine ilişkin detaylı bilgiye yer verilmiştir. 


\section{Araștırmanın Modeli}

Araştırmada nitel araştırma yöntemlerinden durum çalışması deseni kullanılmıştır. Durum çalışmasının en temel özelliği bir ya da birkaç durumun derinliğine araştırılmasıdır. Yani duruma ilişkin etkenler (ortam, bireyler, olaylar, süreçler, vb.) bütüncül bir yaklaşımla araştırılır ve ilgili durumu nasıl etkiledikleri ve durumdan nasıl etkilendikleri üzerine odaklanır (Yıldırım ve Şimşek, 2013).

Çalışmada 2018-2019 Eğitim öğretim yılında Yüksek Öğretim Kurumu tarafından güncelleştirilen lisans düzeyi müzik eğitimi öğretim programında yer alan Türk Halk Müziği Teorisi ve Uygulaması ile Türk Sanat Müziği Teorisi ve Uygulaması derslerinin farklı açılardan değerlendirilmesine ilişkin öğretim elemanlarına görüşme formu uygulanmış ve elde edilen veriler içerik analizi ile analiz edilmiştir.

\section{Çalışma Grubu}

Araştırmanın çalışma grubunu 2019-2020 bahar döneminde müzik eğitimi anabilim dallarında görev yapan, Müzik Teorisi Ve Uygulaması dersini yürüten ve araştırmaya gönüllü olarak katılan farklı üniversitelerden 11 öğretim elemanı oluşturmaktadır. Çalışmada öğretim elemanlarının isimlerinin gizli tutulması için, K1, K2, K3, K4, ...K11 şeklinde kodlar atanmıştır. Öğretim elemanlarının cinsiyet, çalışma yılı ve bulundukları kadrolara ilişkin demografik verileri Tablo 1'de verilmiştir.

Tablo 1

Araştırmanın Çalışma Grubunu Oluşturan Öğretim Elemanlarının Cinsiyet, Çalışma Yılı ve Bulunduklart Kadrolara İlişkin Demografik Veriler Tablosu

\begin{tabular}{cccccc} 
Kat1lımc1 & Cinsiyet & Yaş & Eğitim Durumu & Unvanı & Hizmet Y11 \\
\hline K1 & Kadın & $31-40$ & Doktora & Arş.Gör. & $6-10$ \\
K2 & Kadın & $41-50$ & Doktora & Öğr.Gör. & $16-20$ \\
K3 & Kadın & $41-50$ & Doktora & Dr. Öğr.Üyesi & $11-15$ \\
K4 & Erkek & $31-40$ & Doktora & Dr. Ögr.Üyesi & $16-20$ \\
K5 & Erkek & $31-40$ & Y. Lisans & Öğr. Gör. & $6-10$ \\
K6 & Erkek & $31-40$ & Y. Lisans & Öğr. Gör. & $11-15$ \\
K7 & Erkek & $31-40$ & Doktora & Öğr. Gör. & $11-15$ \\
K8 & Erkek & $41-50$ & Doktora & Prof.Dr. & 21 ve üstü \\
K9 & Erkek & $41-50$ & Doktora & Doçent & $11-15$ \\
K10 & Erkek & $41-50$ & Doktora & Dr. Öğr.Üyesi & $16-20$ \\
K11 & Erkek & 51 ve üzeri & Doktora & Dr. Öğr.Üyesi & 21 ve üstü \\
\hline
\end{tabular}

Tablo 1 incelendiğinde katılımcılardan 3'ü kadın, 8'i erkektir. Katılımcılardan 5'inin yaşları 41-50, 5'inin 31-40, 1 katılımcı ise 51 ve üzeri yaş aralığındadır. 9 katılımcının eğitim durumunun Doktora, 2 katılımcının ise Yüksek lisans olduğu görülmektedir. 4 katılımcının Doktor Öğretim Üyesi, 4 katılımcının Öğretim Görevlisi, 1 katılımcının Profesör Doktor, 1 katılımcının, Doçent ve 1 katılımcının ise Araştırma Görevlisi ünvanına sahip olduğu görülmektedir. Katılımcılardan 2'si 6-10 y1l, 4’ü 11-15 y1l, 3’ü 16-20 yıl, 2'si 21 yıl ve üstü aralığında hizmet yılına sahiptir.

\section{Veri Toplama Aracı}

Çalışmada nitel veri toplama araçlarından yarı yapılandırılmış görüşme formu kullanılmıştır. Yarı yapılandırılmış görüşmeler hem sabit seçenekli cevaplamayı hem de ilgili alanda derinlemesine gidebilmeyi birleştirir (Büyüköztürk, Kılıç, Çakmak, Akgün, Karadeniz ve Demirel, 2009, s.160). Araştırmacılar tarafından geliştirilen formun hazırlanması aşamasında öncelikle konuyla ilgili literatur taraması yapılmıştır. Elde edilen veriler doğrultusunda iki bölümden oluşan yarı yapılandırılmış 
görüşme formu oluşturulmuştur. Formun birinci bölümünde, katılımcıların demografik özelliklerini belirlemeye yönelik sorular, ikinci bölümde ise katılımcıların Türk Halk Müziği Teorisi ve Uygulaması ile Türk Sanat Müziği Teorisi ve Uygulaması derslerine yönelik 6 açık uçlu soru yer almaktadır. Oluşturulan görüşme formu öncelikle kapsam geçerliliği için konu ile ilgili 5 alan uzmanına sunulmuş ve uzmanların görüşleri doğrultusunda 6 açık uçlu soruya 2 kapalı uçlu soru eklenmiştir. İki bölümden oluşan görüşme formu, biri ölçme değerlendirme ve diğeri Türk dili alan uzmanı olmak üzere 2 uzmana sunulmuş ve düzenlemeler yapılmıştır. Görüşme formu çalışma grubunun dışında aynı alanda görev yapan 3 öğretim elemanına pilot uygulama yapılmış ve forma son şekli verilmiştir.

\section{Verilerin Analizi}

Görüşme formu ile elde edilen veriler içerik analizine tabi tutularak analiz edilmiştir. Patton (2014) içerik analizinin hacimli olan nitel materyali alarak temel tutarlılıkları ve anlamları belirlemeye yönelik herhangi bir nitel veri indirgeme ve anlamlandırma çabası girişimlerini ifade etmek için kullanıldığını ve durum çalışmalarında içerik analizinin yapılabileceğini afade etmiştir. Öncelikle veriler derinlemesine analiz edilmiş ve belli temalar altında kodlamalarda bulunulmuştur. Temalar altında oluşturulan bu veriler tablolar halinde sunulmuş ve değerlendirmelerde bulunulmuştur. Bazı veriler katılımcıların doğrudan alıntıları ile desteklenmiştir.

\section{Etik}

"Türk Halk Müziği, Türk Sanat Müziği Teorisi ve Uygulaması Derslerine İlişkin Öğretim Elemanı Görüşleri” başlıklı çalışmanın yazım sürecinde bilimsel, etik ve alıntı kurallarına uyulmuş; çalışma için etik kurul raporu alınmıştır.

\section{Bulgular}

Araştırmanın bu bölümünde katılımcılara yöneltilen sorular ve sorulara verilen yanıtlardan elde edilen veriler tablolar halinde sunulmuştur. Analiz sonucunda elde edilen veriler ayrıca doğrudan alıntılarla desteklenmiştir.

\section{Türk Halk Müziği Teorisi ve Uygulaması Dersine İlişkin Bulgular}

1.soru olarak "Türk Halk Müziği Teorisi ve Uygulaması dersi kapsamında yapılan makamsal solfej ve dikte uygulamaları hangi ses sistemine göre yapılmalı ve nedenleri nedir?" sorusu katılımcılara yöneltilmiş ve verilen yanıtların analiz sonucu Tablo 2'de sunulmuştur.

Tablo 2

Türk Halk Müziği Teorisi ve Uygulaması Dersi Kapsamında Yapılan Makamsal Solfej ve Dikte Uygulamalarının Hangi Ses Sistemine Göre Yapılması Gerektiği ve Nedenlerine İlişkin Veri Tablosu

\begin{tabular}{cll}
\hline Ses Sistemi Tercihi & \multicolumn{1}{c}{ Kat1lımc1 } & Tercih Sebebi \\
\hline 12 Ses Sistemi & K5-K7-K11 & $\begin{array}{l}\text { Öğretimi kolay, evrensel } \\
\text { olmas1, çok sesliliğe } \\
\text { uygun olmas1 }\end{array}$ \\
\hline 17 Ses Sistemi & K1-K2-K3-K4-K6-K8-K9- & $\begin{array}{l}\text { Türk Halk Müziği } \\
\text { Geleneğine uygun, Türk } \\
\end{array}$ \\
& K10 & $\begin{array}{l}\text { Halk Müziği 17 ses } \\
\text { sistemidir. }\end{array}$ \\
\hline 24 Ses Sistemi & - & \multicolumn{1}{c}{-} \\
\hline
\end{tabular}

Tablo 2 değerlendirildiğinde, 8 katılımcının Türk Halk Müziği Teorisi ve Uygulaması dersinde 17 ses sisteminin kullanılması gerektiği fikrini belirtiği görülmektedir. Bunun sebebi olarak Türk halk müziği 17 ses sistemi olduğunu belirtmişlerdir. 3 katılımcın ise 12 ses sisteminin 
kullanılması gerektiği görüşünü belirtmiştir. 3 katılımc1 12 ses sistemini tercih sebebinin öğretiminin kolay olması, evrensel nitelikte olması ve çok sesliliğe uygun olması olarak görüş belirtmiştir. Konuyla ilgili katılımcılara ait doğrudan alıntı örnekleri aşağıda verilmiştir:

“Geleneksel halk müziği seslendirilmesinin 17'li ses sitemi içinde olduğunu biliyorum. Bu nedenle, geleneksel uygulamalarda 17 ses sistemi üzerinden uygulamalar mantıkl."” (K-1)

“Türk halk müziği ses sistemi 17 perdedir.” (K10)

$\mathrm{Bu}$ görüşler doğrultusunda, katılımcıların çoğunluğunun 17 ses sisteminin kullanılması gerektiği ve Türk Halk Müziği geleneğinde kullanılmasından dolayı bu ses sisteminin tercih edilmesi gerektiği görüşünü belirttikleri sonucuna ulaş1labilir.

2.soruda “Türk Halk Müziği Teorisi ve Uygulaması dersi kapsamında makamsal İşitme eğitimine yönelik yapılan uygulamalarda (Solfej, Dikte, Makamsal alg1 v.b.) hangi Enstrüman kullanılmalı ve neden?" sorusu katılımcılara yöneltilmiş ve elde edilen verilerin analiz sonucu Tablo 3'te sunulmuştur.

Tablo 3

Türk Halk Müziği Teorisi ve Uygulaması Dersi Kapsamında Makamsal Isşitme Eğitimine Yönelik Yapılan Uygulamalarda (Solfej, Dikte, Makamsal Algı vb.) Hangi Enstrümanın Kullanılması Gerektiği ve Nedenlerine Illişkin Veriler Tablosu

\begin{tabular}{ccll}
\hline Enstrüman Tercihi & Katılımc1 & $\begin{array}{l}\text { Enstrüman } \\
\text { Türü }\end{array}$ & Tercih Sebebi \\
\hline Evrensel Enstrüman & K5-K7 & Piyano & $\begin{array}{l}\text { Solfej ve dikte uygulamasında duyum açısından } \\
\text { kolaylık, ses gürlüğ̈ü. }\end{array}$
\end{tabular}

\begin{tabular}{clll}
\hline Geleneksel Enstrüman & $\begin{array}{l}\text { K2-K3-K4-K6- } \\
\text { K8-K9-K10 }\end{array}$ & Bağlama & $\begin{array}{l}\text { Türk Halk Müziği geleneğinde olması, Yaygın } \\
\text { olmas1, 17 Ses Sistemine uygunluk açısından, } \\
\text { perdeli olması. }\end{array}$ \\
\hline $\begin{array}{c}\text { Evrensel ve Geleneksel } \\
\text { Enstrüman birlikte } \\
\text { kullanılmalı }\end{array}$ & K1- K11 & $\begin{array}{l}\text { Bağlama } \\
\text { Piyano }\end{array}$ & - Birbirleri ile ilişkilendirmenin katk1 sağlaması. \\
\hline
\end{tabular}

Tablo 3 değerlendirildiğinde, 7 katılımcının Türk halk müziği geleneğinde olması, yaygın olmas1 ve 17 ses sistemine uygun olması sebebiyle geleneksel enstrüman olan bağlamanın kullanılması gerektiğini belirtmişlerdir. 2 katılımcının dikte ve solfej uygulamalarında duyum açısından kolaylık sağlaması ve ses gürlüğünün yüksek olmasından dolayı uygun olduğu görüşünü belirtmişlerdir. 2 katılımc1 ise hem geleneksel hem de evrensel çalgıların birlikte kullanılması gerektiği fikrini belirtmişlerdir. Konuyla ilgili katılımcılara ait doğrudan alıntı örnekleri aşağıda verilmiştir:

“Türk halk müziğinin asıl enstrümanı bağlamadır.” (K-8)

"Geleneksel halk müziğimizi temsil edebilecek en temel ve yerleşik çalgı olması Ses sistemi olarak halk müziğindeki ses sistemini karşllaması her yöreden örnekleri seslendirmeye uygun olması bakımından bağlamayı tercih ederdim." (K-1)

Bu görüşler doğrultusunda, katılımcıların çoğunluğunun Türk Halk Müziği dersinde Türk halk müziği geleneğinde olan, yaygın olarak kullanılan ve 17 ses sistemine uygun geleneksel bir enstrüman olan bağlamanın kullanılmasının uygun olduğu görüşünü belirttikleri söylenebilir. 
3. soru olarak "Türk Halk Müziği Teorisi ve Uygulaması dersinde kullanılabilecek kaynak sayılarının ne ölçüde yeterli olduğunu düşünüyorsunuz?” sorusu katılımcılara yöneltilmiş ve verilen yanıtların analiz sonucu Tablo 4'te sunulmuştur.

Tablo 4

Türk Halk Müziği Teorisi ve Uygulaması Dersinde Kullanılabilecek Kaynak Sayılarının Yeterliliğine İlişkin Veriler Tablosu

\begin{tabular}{|c|c|}
\hline Kaynakların Sayısal Yeterlilik Durumu & Katılımcı \\
\hline Kesinlikle Yeterli & - \\
\hline Yeterli & - \\
\hline Kismen yeterli & K1-K5-K9-K11 \\
\hline Yok denecek kadar az & K2-K6-K7-K8-K10 \\
\hline Kesinlikle yok & $\mathrm{K} 3-\mathrm{K} 4$ \\
\hline
\end{tabular}

Tablo 4 değerlendirildiğinde, 5 katılımcının Türk Halk Müziği Teorisi ve Uygulaması dersine yönelik kullanılabilecek kaynakların yok denecek kadar az olduğu, 4 katılımcının kısmen yeterli olduğu ve 2 katılımcının ise kesinlikle yok görüşünü belirttiği görülmektedir.

$\mathrm{Bu}$ görüşler doğrultusunda, katılımcıların çoğunluğunun belirtilen derse yönelik kullanılabilecek kaynak sayılarının yetersiz olduğunu belirttikleri sonucuna ulaşılabilir.

4.soruda "Türk Halk Müziği Teorisi ve Uygulaması dersi için programda ayrılan 2 dönemlik ve haftada ( 1 saat teori 2 saat uygulama) 3 saatlik süre hedef kazanımlar için ne ölçüde yeterlidir ve önerileriniz nelerdir?" sorusu katılımcılara yöneltilmiş ve verilen yanıtların analiz sonucu Tablo 5 'te sunulmuştur.

Tablo 5

Türk Halk Müziği Teorisi ve Uygulaması Dersi İçin Programda Ayrılan 2 Dönem Haftada (1 Saat Teori 2 Saat Uygulama) 3 Saatlik Süre Hedef ve Kazanımlar İçin Yeterli Olup Olmadı̆̆ ve Önerilere Illişkin Veriler Tablosu

\begin{tabular}{lcccc}
\hline Kat1limc1 & $\begin{array}{c}\text { Ders Süresi } \\
\text { Yeterlilik Durumu }\end{array}$ & \multicolumn{3}{c}{ Öneri } \\
\cline { 3 - 5 } & & $\begin{array}{c}\text { Teorik } \\
\text { Saat }\end{array}$ & $\begin{array}{c}\text { Uygulama } \\
\text { Saati }\end{array}$ & $\begin{array}{c}\text { Dönem } \\
\text { Say1s1 }\end{array}$ \\
\hline K1-K2-K3-K4-K9-K11 & Yeterli & 1 & 2 & 2 \\
K5 & & & 2 & 6 \\
K6-K7- & Yetersiz & 2 & 2 & 2 \\
K8 & Kismen Yeterli & 2 & 2 & 3 \\
K10 & Kismen Yeterli & 1 & 2 & 4 \\
\hline
\end{tabular}

Tablo 5 değerlendirildiğinde, 6 katılımcının Türk Halk Müziği Teorisi ve Uygulaması dersinin Yüksek Öğretim programında belirtildiği gibi haftada 1 saat teorik ve 2 saat uygulama olmak üzere toplam 3 saat ve 2 dönem olmasının yeterli olacağını belirtmişlerdir. 2 katılımcı mevcut yeni programın kısmen yeterli olduğunu 2 saat teorik ve 2 saat uygulama olmak üzere haftada 4 saat ve 2 dönem olması gerektiğini belirtmişlerdir. 1 katılımcı ilgili dersin haftalık ders saati ve dönemi konusunda tamamen yetersiz olduğunu belirtmiş ve haftada 2 saat teorik ve 2 saat uygulama olmak üzere toplam 4 saat ve 6 dönem okutulması gerektiğini belirtmiştir. 2 katılımcı kısmen yeterli olduğunu ve haftalık ders saatinin uygun olduğu fakat dönem sayısı olarak 3 veya 4 dönem olabileceği fikrini belirtmişlerdir. Konuyla ilgili katılımcılara ait doğrudan alıntı örnekleri aşağıda verilmiştir: 
"Mevcut haftalık ders saatinin yeterli olduğunu düşünüyorum fakat 2 dönem değil 4 dönem bu ders verilmeli." $(K-10)$

$\mathrm{Bu}$ doğrultuda, katılımcılarının çoğunluğunun mevcut yükseköğretim programında belirtilmiş olan haftalık ders saatinin ve dönem sayısının yeterli olduğu görüşünü belirttikleri söylenebilir.

\section{Türk Sanat Müziği Teorisi ve Uygulaması Dersine İlişkin Bulgular}

5.soruda "Türk Sanat Müziği Teorisi ve Uygulaması dersi kapsamında yapılan makamsal solfej ve dikte uygulamaları hangi ses sistemine göre olmalı ve neden?" sorusu katılımcilara yöneltilmiş ve verilen yanıtların analiz sonucu Tablo 6'da sunulmuştur.

Tablo 6

Türk Sanat Müziği Teorisi ve Uygulaması Dersi Kapsamında Yapılan Makamsal Solfej ve Dikte Uygulamalarının Hangi Ses Sistemine Göre Yapılması ve Neden Yapılması Gerektiğine İlişkin Veri Tablosu

\begin{tabular}{ccc}
\hline Ses Sistemi Tercihi & Kat1lımc1 & Tercih Sebebi \\
\hline 12 Ses Sistemi & K11 & Uygulama Kolaylığ1 \\
\hline 24 Ses Sistemi & K1-K2-K3-K4-K5-K6-K7- & Türk Sanat Müziğini temsil \\
& K8-K9-K10 & etmesi, TRT arşivi bu ses \\
& & sistemine göre hazırlanmas1 ve \\
& & uygulama kolaylığ sağlamas1. \\
\hline
\end{tabular}

Tablo 6 değerlendirildiğinde, 10 katılımcının Türk sanat müziğini temsil etmesi, TRT (Türkiye Radyo ve Televizyon Kurumu) arşivinin 24 ses sistemine göre hazırlanması ve uygulama kolaylığından dolayı 24 ses sisteminin uygun olduğu görüşünü belirttikleri görülmektedir. 1 katılımc1 ise uygulama kolaylığı sağlayacağından dolayı 12 ses sisteminin uygun olduğu görüşünü belirtmiştir. Konuyla ilgili katılımcılara ait doğrudan alıntı örnekleri aşağıda verilmiştir:

"Dersin içeriği bunu gerektirmektedir.” (K-3)

“Alanın gereği olan 24 ses siteminin kullanılması gerektiğini düşünüyorum.” (K-2)

Bu doğrultuda, katılımcıların çoğunluğunun Türk sanat müziğini temsil etmesi, TRT arşivinin 24 ses sistemine göre hazırlanması ve uygulama kolaylığından dolayı 24 ses sisteminin kullanılmasının uygun olduğu görüşünü belirttikleri söylenebilir.

6. soruda "Türk Sanat Müziği Teorisi ve Uygulaması dersinde kullanılabilecek kaynak sayısı ne ölçüde yeterlidir?" sorusu katılımcılara yöneltilmiş ve verilen yanıtların analiz sonucu Tablo 7'de sunulmuştur.

Tablo 7

Türk Sanat Müziği Teorisi ve Uygulaması Dersinde Kullanılabilecek Kaynakların Sayısal Yeterliliğine Illişkin Veriler Tablosu

\begin{tabular}{|c|c|}
\hline Kaynakların Sayısal Yeterlilik Durumu & Kat1limc1 \\
\hline Kesinlikle Yeterli & - \\
\hline Yeterli & K1 \\
\hline Kismen yeterli & K4-K7-K8-K9-K10-K11 \\
\hline Yok denecek kadar az & - \\
\hline Kesinlikle yok & K2-K3-K5-K6 \\
\hline
\end{tabular}

Tablo 7 değerlendirildiğinde, 6 katılımcının Türk Sanat Müziği Teorisi ve Uygulaması dersi eğitiminde kullanılabilecek kaynak sayısının kısmen yeterli olduğu, 4 katılımcının içbir kaynağın 
olmadığı, 1 katılımcının ise kaynak sayısının yeterli olduğuna ilişkin görüş belirttikleri görülmektedir. $\mathrm{Bu}$ doğrultuda, katılımcıların çoğunluğunun bu ders için kullanılabilecek kaynak sayısının kısmen yeterli olduğuna ilişkin görüş bildirdikleri söylenebilir.

7. soruda "Türk Sanat Müziği Teorisi ve Uygulaması dersi kapsamında makamsal işitme eğitimine yönelik yapılan uygulamalarda (Solfej, Dikte, Makamsal alg1) hangi enstrüman kullanılmalıdır? Enstrümanı tercih sebebiniz nedir?" sorusu katılımcılara yöneltilmiş ve verilen yanıtların analiz sonucu Tablo 8'de sunulmuştur.

Tablo 8

Türk Sanat Müziği Teorisi ve Uygulaması Dersi Kapsamında Makamsal İşitme Eğitimine Yönelik Yapılan Uygulamalarda (Solfej, Dikte, Makamsal Algl vb.) Hangi Enstrümanın Kullanılması Gerektiği ve Nedenlerine Iliş̧kin Veriler Tablosu

\begin{tabular}{clll}
\hline Enstrüman Tercihi & \multicolumn{1}{c}{ Kat1lımc1 } & $\begin{array}{l}\text { Enstrüman } \\
\text { Türü }\end{array}$ & Tercih Sebebi \\
\hline Evrensel Enstrüman & - & - & - \\
\hline Geleneksel Enstrüman & K6-K7-K8-K9- & Kanun & Perdeli olmas1, Sesi net vermesi \\
& K10 & Tambur & Perdeli Olmas1 \\
& K2-K4 & Ud & Yaygin olmas1. \\
\hline $\begin{array}{c}\text { Evrensel ve Geleneksel Enstrüman } \\
\text { birlikte kullanılmalı }\end{array}$ & K1-K11 & $\begin{array}{l}\text { Kanun- } \\
\text { Piyano }\end{array}$ & $\begin{array}{l}\text { Seslerinin gür olmas } \\
\text { ilişkilendirilebilir olacağ1. }\end{array}$
\end{tabular}

Tablo 8 değerlendirildiğinde, 9 katılımcının geleneksel enstrümanların kullanılması gerektiği görüşünü belirttiği görülmektedir. Bu katılımcılardan 5'inin geleneksel enstrümanlardan kanunun perdeli olması ve sesin gür olmasından, katılımcılardan 2'sinin tambur enstrümanının perdeli olmasından ve 2 katılımcının ise Türk sanat müziğinde yaygın olarak kullanılmasından dolayı ud enstrümanın kullanılmasının uygun olacağı görüşünü belirttiği görülmektedir. 2 katılımcı ise hem evrensel bir enstrüman olan piyanonun hem de geleneksel enstrümanlardan kanunun ses gürlüğü açısından uygun olacağ 1 ve birbirleri ile ilişkilendirilebileceği görüşü ile ikisinin birlikte kullanılmasının uygun olacağı görüşünü belirtmiştir. Konuyla ilgili katılımcılara ait doğrudan alıntı örnekleri aşağıda verilmiştir:

"Kanun, tambur, gibi geleneksel çalgllar Türk müziği ses sistemine ait perdeleri rahatllkla icra edebilecek yegâne yapıya sahip çalgılardır." (K-9)

"Bu ders için hem sesinin gürlüğ̈̈ hemde perdeli olmasından dolayı en uygun çalgı geleneksel bir çalgı olan kanundur. Bu çalgı derste ayrıca uygulama kolaylığı sağlayacağını düşünüyorum." (K10)

$\mathrm{Bu}$ doğrultuda, katılımcıların çoğunluğunun geleneksel enstrümanların kullanılması gerektiği, geleneksel enstrümanlardan kanun'un hem perdeli olması hem de sesinin gür olmasından dolayı bu ders için uygun bir enstrüman olacağı görüşünü belirttikleri söylenebilir.

8. Soruda "Türk Sanat Müziği Teorisi ve Uygulaması dersi için programda ayrılan 2 dönemlik ve haftada ( 1 saat teori 2 saat uygulama) 3 saatlik süre hedef ve kazanımlar için ne ölçüde yeterlidir? Bu ders sizce kaç dönem ve haftada (teori ve uygulama olarak) kaç saat olmalıdır?" sorusu katılımcılara yöneltilmiş ve verilen yanıtların analiz sonucu Tablo 9'da sunulmuştur. 
Tablo 9

Türk Sanat Müziği Teorisi ve Uygulaması Dersi İçin Programda Ayrılan 2 Dönem Haftada (1 Saat Teori 2 Saat Uygulama) 3 Saatlik Süre Hedef ve Kazanımlar Için Yeterli Olup Olmadığ ve Önerilere Illişkin Veriler Tablosu

\begin{tabular}{lcccc}
\hline Kat1lımc1 & Ders Süresi Yeterlilik Durumu & \multicolumn{2}{c}{ Öneri } \\
& & $\begin{array}{c}\text { Teorik } \\
\text { Saat }\end{array}$ & $\begin{array}{c}\text { Uygulama } \\
\text { Saati }\end{array}$ & $\begin{array}{c}\text { Dönem } \\
\text { Say1s1 }\end{array}$ \\
\hline K1-K2-K3-K4-K9-K11 & Yeterli & 1 & 2 & 2 \\
\hline K5 & Kismen Yeterli & 2 & 1 & 2 \\
K6-K7 & Kismen Yeterli & 2 & 2 & 2 \\
K8 & Kismen Yeterli & 1 & 2 & 3 \\
K10 & Kismen Yeterli & 1 & 2 & 4 \\
\hline
\end{tabular}

Tablo 9 değerlendirildiğinde, 6 katılımcının programda belirtilmiş olan 2 dönem ve haftada 1 saat teorik ve 2 saat uygulama olmak üzere toplam 3 saatlik dersin yeterli olduğuna yönelik görüş belirttiği görülmektedir. Diğer 5 katılımcı ise mevcut ders programının kısmen yeterli olduğunu belirtmişlerdir. Bu katılımcılardan 2'si 2 dönemlik bir programda haftada 2 saat teorik ve 2 saat uygulama olmak üzere toplamda 4 saatlik bir ders olması gerektiğine ilişkin görüş belirtmiştir. 1 katılımcı dönem sayısını yeterli bulurken haftalık 2 saat teorik 1 saat uygulama olması gerektiği, 1 katılımcı haftalık ders saatlerinin uygun olduğu fakat dönem sayısının 3 olması gerektiği ve 1 katılımcı ise haftalık ders saatinin yeterli olduğunu fakat dönem sayısının 4 olması gerektiği fikrini belirtmişlerdir.

"En az iki dönem, haftada iki saat teorik, bir saat uygulama şeklinde olmast yararlı olabilir." $(K-5)$ $(K-7)$

“Teorinin en az iki saat olması konuların aktarılması ve anlaşılabilirliğini kolaylaştıracaktır."

Bu doğrultuda, katılımcılarının çoğunluğunun Türk Sanat Müziği Teorisi ve Uygulaması dersi için belirtilmiş olan haftada 1 saat teorik 2 saat uygulama olmak üzere toplam 3 saat ve 2 dönemlik sürenin bu dersin hedef ve kazanımları için yeterli olacağı görüşünü belirttikleri söylenebilir.

\section{Sonuç, Tartışma ve Öneriler}

Çalışmada katılımcıların görüşlerinden elde edilen sonuçlara göre araştırmaya katılan öğretim elemanları Türk Halk Müziği Teorisi ve Uygulaması dersinde özellikle Türk halk müziğinin geleneğinde yer alan 17 ses sisteminin kullanılmasının uygun olacağını, Türk Halk Müziği Teorisi ve Uygulaması dersinde kullanılması gereken enstrümanın geleneksel bir çalgı olması gerektiğini, Türk halk müziği kültüründe kullanılan geleneksel özelliğe sahip bağlama enstrümanının bu müzik türünde sıklıkla kullanılmasını, perdeli bir çalgı olması ve 17 ses sistemine uygun bir yapıda olmasından dolayı ders içi uygulamalarda kolaylık sağlayacağını belirtmişlerdir.

Bu sonuçlara göre Türk Halk Müziği Teorisi ve Uygulaması dersinde kullanılabilecek kaynak sayısının yetersiz olduğu ve hazırlanacak olan kaynakların öğrenci seviyelerine uygun olarak hazırlanması gerektiği anlaşılmaktadır. Konuya ilişkin Bulut (2008) çalışmasında, geleneksel Türk halk müziği kaynaklı eserlerin belli kategorilere göre sınıflandırarak (eğitim müziği, konser müziği ile biçimsel, yöresel, modal-tonal özellikleri) eğitimde kullanılabilir hale getirilmesi gerektiğini belirtmiştir. 
Katılımcılara göre 2018-2019 Eğitim öğretim yılında Yüksek Öğretim Kurumu tarafından uygulamaya konulan müzik öğretmenliğgi lisans programında Türk Halk Müziği Teorisi ve Uygulaması dersi için ayrılan haftada 1 saat teorik, 2 saat uygulama olmak üzere toplam 3 saat ve 2 dönemlik sürenin bu dersin hedef ve kazanımları için yeterli olduğunu, Türk Sanat Müziğini Teorisi ve Uygulaması dersinde 24 ses sisteminin kullanılmasının uygun olacağı, TRT Türk sanat müziği repertuarının 24 ses sistemine göre hazırlanması ve derste uygulama kolaylığı sağlayacağından dolayı bu ses sisteminin kullanılmasının gerekli olduğunu belirtmişlerdir.

Türk Sanat Müziği Teorisi ve Uygulaması dersinde kullanılabilecek kaynak sayısının kısmen yeterli olduğu, Türk Sanat Müziği Teorisi ve Uygulaması dersinde 7 öğretim elemanı geleneksel enstrümanlardan kanunun hem perdeli olması hem de sesinin gür olmasından dolayı kullanımının bu ders için uygun bir enstrüman olacağını belirtmişlerdir.

Araştırmada bir diğer sonuç olarak 6 öğretim elemanı Türk Sanat Müziği Teorisi ve Uygulaması dersi için ayrılan 1 saat teorik 2 saat uygulama olmak üzere toplam 3 saat ve 2 dönemlik sürenin bu dersin hedef ve kazanımlarını gerçekleştirmek için yeterli olacağını ifade etmişlerdir.

Çalışmada elde edilen sonuçlara dayanarak aşağıdaki öneriler getirilmiştir:

- Türk Halk Müziği, Türk Sanat Müziği Teorisi ve Uygulaması derslerinin hedef ve davranışlarına yönelik hazırlanmış nitelikli kaynak sayıları artırılabilir.

- Öğretim programında yeni uygulamaya konulan bu dersler ile ilgili öğretim elemanlarının görüşlerinin yanında öğrencilerin görüşlerine de başvurarak daha geniş kapsamlı araştırmalar yapılabilir.

- Öğrenci seviyeleri ile eğitim programı hedef davranışları dikkate alınarak Türk halk müziği ve Türk sanat müziği repertuvarı tasnif edilerek ve müzik eğitiminde kullanılmak üzere düzenlenebilir.

- Boylamsal çalışmalarla bu dersler için programda ayrılmış eğitim süresinin yeterliliğine ilişkin değerlendirmeler yapılabilir.

- Derslerin uygulanması aşamasında kullanılması önerilen enstrümanlarla ilgili deneysel çalışmalar yapılarak enstrümanların işlevselliği değerlendirilebilir.

- Şimdiye kadar sıklıkla kullanılan tampere ses sistemininden farklı olarak kullanılacak olan geleneksel 17'li ve 24'lü ses sistemlerinin uygulama durumuna ilişkin araştırmalar yapılabilir.

\section{Kaynaklar}

Albuz, A. (1996). AGSL Müzik bölümlerinde uygulanan Müziksel İşitme-Okuma dersinin önemi, içeriği ve sorunları. 28-30 Kasım 1996, I. Ulusal Anadolu Güzel Sanatlar Liseleri Müzik Bölümleri Sempozyumu, Bursa.

Bilgin, S. (1998). Illköğretim okullarının 2. kademesinde müzik ĕgitiminde kullanılan şarkaların Gazi Üniversitesi Gazi Ĕgitim Fakültesi müzik eğitimi bölümü çıkışl müzik öğretmenleri tarafindan piyano ile eşliklenmesi. Doktora Tezi. Gazi Üniversitesi, Fen Bilimleri Enstitüsü, Ankara.

Bulut, F. (2008). Piyano eğitiminde geleneksel Türk halk müziği kaynaklı eserlerin seslendirilmesine yönelik oluşturulan bir "çoklu analiz modeli" ve bu modelin öğrenci başarısı üzerine etkileri. Doktora Tezi. Gazi Üniversitesi, Eğitim Bilimleri Enstitüsü, Ankara.

Büyüköztürk, Ş., Kılıç Çakmak, E. Akgün, Ö. E., Karadeniz, Ş. ve Demirel, F. (2009). Bilimsel araştırma yöntemleri. Ankara: Pegem Akademi. 
Er, A. (2012). Güzel sanatlar ve spor liselerinin müzik bölümlerinde okutulmakta olan Müziksel İsitme Okuma ve Yazma derslerindeki türk müziğine dayall etkinliklere ilişkin öğretmen ve öğrenci görüşleri. Yüksek Lisans Tezi. Gazi Üniversitesi, Eğitim Bilimleri Enstitüsü, Ankara.

Hasar, S. (2016). Müziksel İşitme Okuma ve Yazma dersinde uygulanan geleneksel Türk müziği solfej eğitiminin değerlendirilmesi. Yüksek Lisans Tezi. Uludağ Üniversitesi, Eğitim Bilimleri Enstitüsü, Bursa.

Özçelik, S. (2010). Müzikal dikte ve solfej. Ankara: Başkent.

Özgür, Ü. ve Aydoğan, S. (2015). Müziksel işitme okuma eğitimi ve kuram. Ankara: Sözkesen.

Öztürk, B. (2011). Müziksel İşitme-Okuma ve Yazma (MIOY) derslerinde makamsal uygulamalara ilişkin durum saptamasına yönelik ögretmen görüşleri. Yüksek Lisans Tezi. Gazi Üniversitesi, Eğitim Bilimleri Enstitüsü, Ankara.

Patton, M. Q. (2014). Nitel araştırma ve değerlendirme yöntemleri. (Çev. M. Bütün, S. B. Demir). Ankara: Pegem Akademi.

Tarman, S. (2006). Müzik eğitiminin temelleri. Ankara: Müzik Eğitimi.

Uçan, A. (2005). Müzik eğitimi temel kavramlar-ilkeler-yaklaşımlar ve Türkiye'deki durum. Ankara: Evrensel Müzik Evi.

Yayla, F. (2005). Müziksel işitmenin temel prensipleri. Mehmet Akif Ersoy Üniversitesi Eğitim Fakültesi Dergisi, (12), 28-38.

Yıldırım, A. ve Şimşek, H. (2013). Sosyal bilimlerde nitel araştırma yöntemleri. Ankara: Seçkin.

Yıldız, F. (2013). Müziksel İşitme Okuma ve Yazma derslerindeki makamsal dizilerin ögrretiminde Sefai Acay yaklaşımının kullanılabilirliği. Yüksek Lisans Tezi. Afyon Kocatepe Üniversitesi, Sosyal Bilimler Enstitüsü, Afyonkarahisar. 


\section{Extended Abstract}

\section{Introduction}

Departments of music education are among the key institutions that provide vocational education in music. The "Musical Hearing, Reading and Writing" course was provided by departments of music education in the first three years, meaning within the first six semesters of the study program, until 2018. The content of the course included traditional Turkish music theories and also the theory and practice-oriented target achievements towards international music genres. According to the changes made in the undergraduate degree programs by the Council of Higher Education, the "Musical Literacy and Auditory Learning" course was canceled and replaced by western music theory and practice, Turkish classical music theory and practice and Turkish folk music theory and practice.

In the case that these courses which have been included in the program are considered as independent disciplines, it is important that these courses have specific course materials and employ specific instruction methods and techniques. Such courses that have been put into practice as individual disciplines bring along different questions regarding their implementation in departments of music education that provide education for prospective music teachers. These questions include which sound systems and instruments should be employed for the instruction of the courses Turkish folk music theory and practice and Turkish classical music theory and practice which form the basis of our traditional music, which course materials should be used and what will be the length of a time allocated for the course and whether this time will be sufficient. Opinions of instructors have key importance to prevent the setbacks in the implementation of these courses that will be introduced for the first time and to provide a productive, clear and permanent learning. In this line, the aim of this research study is to identify the opinions of the instructors on sound systems, instruments, course materials and length of the time allocated for the course, and status of implementation regarding Turkish folk music theory and practice and Turkish classical music theory and practice courses that will be introduced for the first time in the scope of music education program.

\section{Method}

The study employed a semi-structured interview form as a qualitative data collection tool. A literature review was conducted before the preparation of the form that was developed by the researchers. Based on the collected data, the semi-structured interview form consisted of two sections was shaped. The first section of the form included questions to identify the demographic characteristics of the participants, and the second section of the form included 6 open-ended questions to identify participants' opinions on Turkish folk music theory and practice, and Turkish classical music theory and practice courses. The interview form was presented to 5 field experts for ensuring the content validity, and in line with the suggestions of the experts, 2 closed-ended questions were added to 6 open-ended questions provided in the form. The interview form which consisted of two sections was presented to 2 experts specialized in assessment and evaluation, and the Turkish language. Afterward, re-arrangements were made according to their feedback. In addition to the study group, a pilot application of the interview form was performed with 3 instructors working in the same field and the form was given its final shape. The data collected through the interviews were analyzed in detail using the content analysis method and relevant themes were created. The data were evaluated under the created themes and presented in tables. Furthermore, direct quotations were made from the answers of the participants to support the data.

\section{Result}

The results of the study showed that the use of 17 sound system in Turkish folk music theory and practice course would be appropriate, the traditional instrument, 'baglama', would be a useful instrument for in-class applications given its fretted structure and appropriateness for the sound system, and the materials that can be used for the delivery of the course are limited. 
On the other hand, the study results revealed that the use of 24 sound system in Turkish classical music theory and practice would be appropriate, the traditional instrument, 'Qanun', would be a useful instrument for in-class applications given its fretted structure and the instrument's loudness of sound, and the materials that can be used for the delivery of the course are partially sufficient but the number of these materials should be amplified.

Furthermore, the results identified that the allocated time for both courses, which is 2 semesters and 3 lecture hours per hour, would be sufficient for delivering the objectives of the course. The assessment of the study results showed that there is a need to enhance the number of course materials relevant to the level of students, based on the target achievements of the courses, and also to create a repertoire for Turkish classical music and in Turkish classical music.

\section{Discussion and Conlusion}

The courses, Turkish folk music theory and practice and Turkish classical music theory and practice -which are included in the undergraduate program of the departments of music education for the teaching Turkish folk music and Turkish classical music, are important components of our culture and also fundamental subjects in the field of music education. It can be argued that there is a direct correlation between the quality of education provided through these courses and prospective teachers' future performance as highly competent teachers in their professional lives. From this aspect, the methods and techniques that will be used in the learning and teaching processes of the Turkish folk music theory and practice and Turkish classical music theory and practice courses should be identified through a joint approach. The results of this study revealed that the materials required for delivering these courses are limited. Carrying our traditional music to the next generations in the right way depends on the quality of education that we provide today. 